\author{
열팽창캡슐 적용 발포폴리프로필렌의 물리적 특성 비교 \\ 하진욱 ${ }^{\dagger}$ 정선경 - 이평찬 - 황예진 - 남병국* - 한인수 $* *$ - 곽성복*** - 이재용*** \\ 자동차부품연구원, *롯데케미칼, **현대자동차, ***덕양산업 \\ (2014년 5월 20일 접수, 2014년 6월 27일 수정, 2014년 6월 27일 채택)
}

\title{
Physical Properties of Polypropylene Foam Blended with Thermally Expandable Microcapsules
}

\author{
Jin Uk Ha ${ }^{\dagger}$, Sun Kyung Jeoung, Pyoung-Chan Lee, Ye Jin Hwang, Byung Kook Nam*, \\ In-Soo Han**, Sung Bok Kwak***, and Jae Yong Lee*** \\ Lightweight \& Convergent Materials R\&D Center, Korea Automotive Technology Institute, Chungnam 330-912, Korea \\ *The $3^{\text {rd }}$ Research Team, Lotte Chemical, Daejeon 305-726, Korea \\ **Polymeric Materials Research Team, Hyundai Motors, Gyeonggi 445-706, Korea \\ ***Advanced Engineering Team, Duckyang Ind. Co., Ltd, Gyeonggi 443-766, Korea
}

(Received May 20, 2014; Revised June 27, 2014; Accepted June 27, 2014)

\begin{abstract}
초록: 열팽창 캡슐은 코어에 위치한 발포가스가 기화온도 이상이 될 경우 캡슐을 팽창시켜 상온상태보다 큰 부피를 지닌 형태를 이루게 되는데 이러한 특성을 이용하여 플라스틱의 발포소재로 적용이 가능하다. 본 연구에서는 자동 차 내외장재 용도로 가장 많이 사용되는 폴리프로필렌(polypropylene, PP)을 베이스 원료로 하여 기존 화학발포제와 열팽창 캡슐을 이용하여 PP 폼을 제조하였으며, 제조된 시편의 물리적인 특성을 비교하였다. 화학 발포제와 열팽창 캡슐을 적용하여 제조된 PP 폼은 모두 첨가된 발포제 및 열팽창 캡슐 함량 증가에 따라 시편의 밀도가 감소하였고, 인장강도를 포함한 기계적 물성 또한 감소하였다. 하지만, 열팽창 캡슐을 이용해 제조된 PP 폼의 경우는 화학 발포 제를 적용하여 만들어진 시편대비 충격강도 감소량이 크지 않았다. 발포제 종류별로 상이한 물리적 특성을 분석하 기 위하여 PP 폼의 매트릭스를 분석하였으며, 다른 형상의 모폴로지를 관찰하였다.
\end{abstract}

\begin{abstract}
Thermally expandable microcapsules (TEMs) can be expanded upon heating since the activation energy of liquid hydrocarbon at the core of the TEMs increased at high temperature. Due to this property, TEMs are widely used in the industry as blowing agents or light-weight fillers. In this article, chemical blowing agent and TEM were used for making polypropylene (PP) foams, and their mechanical properties were compared. Physical properties (tensile strength, impact strength etc.) of PP foams decreased with increasing the amount of blowing agents while weight of specimen decreased. However, PP foam produced with TEMs showed higher impact strength than the one with a chemical blowing agent. In order to figure out the difference of impact strength, the morphology of PP foamed was investigated. Expanding properties of TEM can be controlled by changing core back distance.
\end{abstract}

Keywords: polypropylene, thermally expandable microcapsule, foaming, chemical blowing agent, mechanical properties, core back.

\section{서 론 \\ 최근, 선진국을 중심으로 감소하는 석유자원과, 자국의 환 경보호를 위한 $\mathrm{CO}_{2}$ 발생량 규제와 관련하여 강화된 법을 자 동차 산업에 적용하고 있으며, 이러한 이유로 인하여 자동차 산업에서는 엔진성능 향상 외에도 차량의 연비를 효율적으로}

${ }^{\dagger}$ To whom correspondence should be addressed.

E-mail: juha@katech.re.kr
향상시킬 수 있는 방안으로 경량화와 관련된 다양한 연구를 수행하고 있다. ${ }^{1,2}$ 따라서 자동차용으로 사용될 수 있는 소재 중 가장 비중이 낮은 고분자 소재의 적용은 복합소재를 중심 으로 사용량이 점차 증가하고 있는 추세이다. ${ }^{3}$ 발포성형은 이 처럼 낮은 고분자 소재의 추가적인 경량효과 뿐만 아니라 소 재의 원가절감을 가능케 하므로, 기계적 물성이 허용하는 범 위 내에서 고분자 소재의 추가적인 경량효과를 달성하기 위 하여 다양한 고분자 발포성형 관련 연구가 진행되고 있다. ${ }^{4-6}$ 일반적으로 자동차에 가장 많이 사용되는 고분자 수지는 폴 
리프로필렌(polypropylene, PP)으로 고분자 소재 가운데서도 가장 가벼운 수지 중에 하나이며, 수지의 특성 제어를 통하 여 물성제어가 가능하기 때문에 이미 오래 전부터 다양한 자 동차 부품으로 활용되고 있다. 일반적으로 $\mathrm{PP}$ 와 같은 결정성 수지는 용융점 영역에서 점도변화가 크기 때문에 가공 영역 이 넓지 않으며, 발포셀의 균일한 성장을 위하여 strain hardening, elongational viscosity 등이 좋아야 하나, $\mathrm{PP}$ 의 경 우는 이러한 특징이 열세여서 사용에 제약이 있는 편이다. ${ }^{5}$ 또한 발포성형의 경우 종종 가스로 기인한 제품의 외관불량 (silver streaks, swirl mark) 등이 원인이 되는 문제점이 있다. ${ }^{6}$ 열팽창 캡슐(thermally expandable microcapsule, TEM)의 경 우 1970년대 다우 케미컬에서 처음 개발한 이후, 다양한 용 도로 적용이 증가하고 있다. ${ }^{7}$ 열팽창 캡슐의 경우는 일반적으 로 상온에서 액체인 액화수소가스가 발포제로 캡슐의 중심 (core)에 위치하며, 아크릴로니트릴 공중합체 고분자(일반적 으로 아크릴 계열 공중합체)가 쉘(shell)을 구성하여, 상온에 서는 일반 파우더 형상이나, 고온 노출시 core에 위치한 액화 수소가 기화하여 캡슐을 팽창시켜 발포제로 적용될 수 있다. ${ }^{8}$ 열팽창 캡슐의 경우 일반적으로 약 $150 \sim 200{ }^{\circ} \mathrm{C}$ 에서 팽창하 여 초기 크기대비 약 50 100배 가량 부피팽창을 한다. 또한 일반적인 화학발포제(chemical blowing agent: CBA)와 달리 가스가 표면으로 나오지 않아, 사출 가공 시 외관특성이 기 존 발포공정 대비 우세하다. ${ }^{9}$ 이러한 특성을 이용하여 일본계 열팽창 캡슐 제조사들은 여러 제품에 열팽창 캡슐을 적용하 는 시도를 하였으며, ${ }^{10,11}$ 일부 자동차용 고분자 소재에도 적 용한 것으로 보고하였다. ${ }^{12}$ 열팽창 캡슐을 사출 가공시 적용 하기 위해서는 기존 열팽창 캡슐 대비 내열특성을 향상하여, 고온에서 팽창되며 캡슐의 분해가 일어나지 않아야 한다. Jonsson과 Nordin 등은 열팽창 캡슐의 팽창 시작온도를 조절 하기 위하여 다양한 형태의 가교제를 실험하였으며, 1,4butanediol dimethacryate와 diallyl carbonate를 활용하여 열팽 창 캡슐의 조기팽창없이 팽창온도를 향상하는 실험결과를 보 여주었다. ${ }^{13}$ 발포가스의 기화점에 따라서 열팽창 캡슐의 성 능차이가 다양하게 발생하며, 기화점이 상이한 발포가스 실 험을 통하여 최소 $120{ }^{\circ} \mathrm{C}$ 부터 최대 $205{ }^{\circ} \mathrm{C}$ 까지 다양한 팽창 시작온도를 보유한 열팽창 캡슐이 제조될 수 있음을 보여 주었다. ${ }^{13}$ 열팽창 캡슐의 다양한 적용을 위한 캡슐 중합과 관 련된 많은 연구가 수행되고 있는 것에 비해 열팽창 캡슐을 실제 사출가공하여 소재의 물성에 대한 변화와 기존 발포공 정을 통하여 제조된 시편과의 물리적 특성 비교한 연구결과 가 발표된 사례는 많지 않다. ${ }^{14-16}$ 본 연구에서는 자동차용 내 장부품으로서 향후 경량화 효과를 달성할 수 있는 열팽창 캡슐의 적용가능성을 판단하기 위한 기초연구로 열팽창 캡 슐을 적용한 PP 발포소재의 물리적 특성과 기존 화학발포제 를 이용한 발포공정을 통하여 제조된 소재와의 물성을 비교 하였다.

\section{실 험}

재료. 본 실험을 위하여 사용된 폴리프로필렌(PP)은 롯데 케미칼의 HFJ-371을 사용하였으며, 발포사출용 PP인 HFJ371은 가지화 구조를 가지며, 일반적인 PP 대비 용융장력이 높아 안정적인 발포셀 형성에 유리하여 발포성형에 적합한 $\mathrm{PP}$ 이며 수지의 $50 \mathrm{~g} / 10 \mathrm{~min}$ 의 유동특성을 갖고 있다. 실험에 앞서 측정된 발포사출용 $\mathrm{PP}$ 의 기본물성은 Table 1에 명시하 였다. 화학발포제는 일본 EIWA사의 H-3510(Gas volume $47 \mathrm{~mL} / \mathrm{g}$ )를 사용하였다. 화학발포제 H-3510는 롯데케미칼에 서 HFJ-371 중 가장 효율적으로 발포공정이 이루어지는 발 포제로 롯데케미컬의 추천으로 선정된 소재이다. H-3510은 Sodium bicarbonate와 LDPE가 혼합된 마스터 배치타입의 소 재이다. 사출 가공시 화학발포제와 비교를 위해 사용한 열팽 창 캡슐은 일본 마츠모토사의 Micropearl F-190D을 사용하 였으며, F-190D의 팽창 시작온도는 약 $160{ }^{\circ} \mathrm{C}$ 이며, 최대 가 공온도는 약 $220^{\circ} \mathrm{C}$ 이다. 실험에 사용된 화학발포제와 열팽 창 캡슐의 양은 모두 $3.2 \mathrm{phr}$ 로 동일하게 설정하였다.

발포공정. PP 수지와 화학발포제 및 열팽창 캡슐은 사전에 별도로 혼합되어 사출기에 주입되었으며, 사용된 사출기는 Ube사의 180 톤 전동사출기를 사용하였다. 사출 가공온도와 노즐부 온도는 $190{ }^{\circ} \mathrm{C}$ 이며, $\mathrm{H} 1190{ }^{\circ} \mathrm{C}, \mathrm{H} 2185^{\circ} \mathrm{C}, \mathrm{H} 3$ $175^{\circ} \mathrm{C}, \mathrm{H} 4165^{\circ} \mathrm{C}$ 로 설정되었으며, 금형 온도는 $50{ }^{\circ} \mathrm{C}$, 냉각 시간은 30 초로 설정하였다. 수지주입 후 0.5 초 이후에 $2 \mathrm{~mm}$ 금형후진(core back)하여 동일 조건하에서 화학발포제와 열 팽창 캡슐이 발포할 수 있도록 하였다. 일반적으로 화학발포 제의 가공조건 범위가 열팽창 캡슐보다 넓으며, 따라서 본 실 험에서는 열팽창 캡슐의 가공조건과 화학발포제의 가공조건 이 겹치는 영역에서 동일 조건하에서 사출 가공하였다. Core back에 따른 캡슐의 발포 정도를 관찰하기 위하여 금형 후진 거리를 $1.0,1.5,2.0,2.5 \mathrm{~mm}$ 로 설정하여 시편의 밀도변화를 관찰하였다.

분석. 최종 사출물은 사출 후 1 일 동안 상온에서 aging된 이후에 UTM 장비(MTDI UT-100F)를 이용하여 인장 및 굴

Table 1. Physical Properties of HFJ-371

\begin{tabular}{cccc}
\hline & TEST Method & Unit & Result \\
\hline MFI $\left(230^{\circ} \mathrm{C}\right)$ & ASTM D 1238 & $\mathrm{g} / 10 \mathrm{~min}$ & 51.0 \\
Density & ASTM D 792 & $\mathrm{g} / \mathrm{cm}^{3}$ & 1.02 \\
Tensile strength & ASTM D 638 & $\mathrm{MPa}$ & 22 \\
Flexural modulus & ASTM D 790 & $\mathrm{MPa}$ & 19,483 \\
Flexural strength & ASTM D 790 & $\mathrm{MPa}$ & 33 \\
HDT & ASTM D 648 & ${ }^{\circ} \mathrm{C}$ & 121.2 \\
Izod $\left(23^{\circ} \mathrm{C}\right)$ & ASTM D 256 & $\mathrm{J} / \mathrm{m}$ & 31 \\
\hline
\end{tabular}

*In the experiment results may be different from the properties presented by the producer 
곡강도가 측정되었으며, 밀도는 Alfa Mirage, MD-300S를 통 하여 측정되었고, 단면은 Hitachi S-4200 전자주사현미경과, 액체질소에서 급냉한 뒤 파단면을 광학현미경(Trinocular Zoom Stereo Microscope: JNOEC)을 통하여 관찰하였다. 열 팽창 캡슐의 내열특성 분석을 위하여 TGA 및 DSC 분석은 질소조건 하에서 승온 $\left(20^{\circ} \mathrm{C} / \mathrm{min}\right)$ 의 조건으로 분석하였으며, 온도상승에 따른 열팽창 캡슐의 부피변화 특성으로 측정이 어려움에 따라 시편의 양은 1 2 mg 일반적인 경우보다 적은 양을 측정하였다. 캡슐의 입도크기는 Malvern 2000E을 이용 하여 건조된 파우더의 입도크기를 분석하였다. 열팽창 캡슐 의 팽창성능의 간이 평가를 위하여 유리용기에 열팽창 캡슐 을 넣고 oil bath에서 5 분간 열을 가한 후 초기 상태의 열팽 창 캡슐과의 직경을 현미경을 통하여 관찰하였다.

\section{결과 및 토론}

열팽창 캡슐 기초분석. 고분자 수지의 발포성형 시 주로 사용되는 화학발포제와는 달리 열팽창 캡슐을 이용한 발포사 출의 연구논문은 극히 적으며, 본 연구에서 수행에 앞서 열 팽창 캡슐의 열적 특성을 분석하여 사출 조건을 최적화 하기 위한 기초 실험을 실행하였다. Figure 1에서는 열팽창 캡슐의 TGA 및 DSC 결과를 보여주고 있다. 일반적인 고분자 소재 와 달리 열팽창 캡슐은 코어에 있는 발포가스의 기화로 인하 여 시편이 고정되지 않고 변형이 발생하여 데이터의 노이즈 를 발생시켜 TGA 및 $\mathrm{DSC}$ 측정이 매우 어렵다. TGA 분석 을 통해서 열팽창 캡슐에 함유된 발포가스의 함량을 유추할 수 있는데, Figure 1 의 분석결과에 따르면 약 $160^{\circ} \mathrm{C}$ 부터 질 량비의 변화가 발생하게 되며 제품 스펙에 명시된 팽창조건 을 고려할 경우 팽창이 시작되는 온도 $160 \sim 220^{\circ} \mathrm{C}$ 에서의 무
게감소율이 코어에 위치한 발포가스의 함유량으로 판단된다. 이 온도에서의 열팽창 캡슐의 무게감소율은 약 $30 \mathrm{wt} \%$ 정도 이며, 따라서 열팽창 캡슐의 발포가스 구성비를 유추할 수 있 다. $300{ }^{\circ} \mathrm{C}$ 이상에서 발생된 무게감소는 열팽창 캡슐의 셀을 구성하는 아크릴로니트릴 공중합체의 분해에 따른 영향으로 판단된다. 열팽창 캡슐의 정확한 기화온도는 DSC 분석을 통 해서 추가 확인하였다. Figure 1의 DSC 결과를 보면 약 $190{ }^{\circ} \mathrm{C}$ 에서 열팽창 캡슐은 흡열피크를 보이는데, 캡슐 내부 에 있는 발포가스의 기화로 인하여 발생한 것으로 알 수 있 다. 하지만, 발포가스의 기화로 인한 피크 외에 캡슐의 셀의 열적 특성과 관련된 피크는 관찰되지 않았는데, 이는 DSC 측 정시 캡슐의 팽창으로 인하여 시료의 양을 최소화 했기 때문 에 분석되지 않은 것으로 판단된다. 열팽창 캡슐의 초기 직 경(Figure 2)은 약 $20 \mu \mathrm{m}$ 이며, 입도크기의 균일도는 현탁중 합을 통하여 만들어진 중합물임을 고려할 때 상대적으로 좋 은 수준으로 판단된다. 이는 상업용 열팽창 캡슐의 경우 최 종제품을 물리적으로 필터링하는 과정을 거치는 것에 따른 것으로 판단된다. 균일한 입도는 열팽창 캡슐을 이용한 사출 부품 제조시 경량화 효율을 높이는데 도움이 될 수 있을 것 이다. ${ }^{12}$ 열팽창 캡슐의 팽창성능을 분석하기 위하여 열팽창 캡슐을 $200{ }^{\circ} \mathrm{C}$ 오일배스에 노출한 후 열팽창 캡슐의 크기는 초기직경 약 $20 \mu \mathrm{m}$ 에서 캡슐별로 팽창성능의 차이는 있으나 약 $196 \mu \mathrm{m}$ 까지 팽창까지 팽창하는 결과를 보여주었다(Figure 3).

열팽창 캡슐 적용 PP 발포시편의 물성분석. 일반적으로 고분자 수지를 발포할 경우 연속적인 수지 매트릭스에 void 가 발생하여 고분자 수지의 밀도를 감소시킬 수 있으나, 같 은 이유로 수지의 물성도 감소되는 특성을 보인다. 본 연구 에서는 동일함량의 화학발포제와 마이크로 캡슐을 적용하여

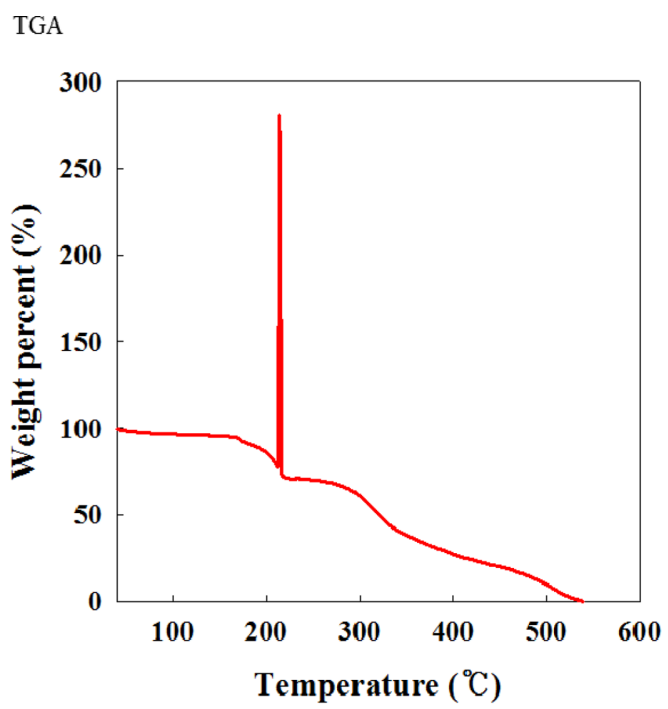

DSC

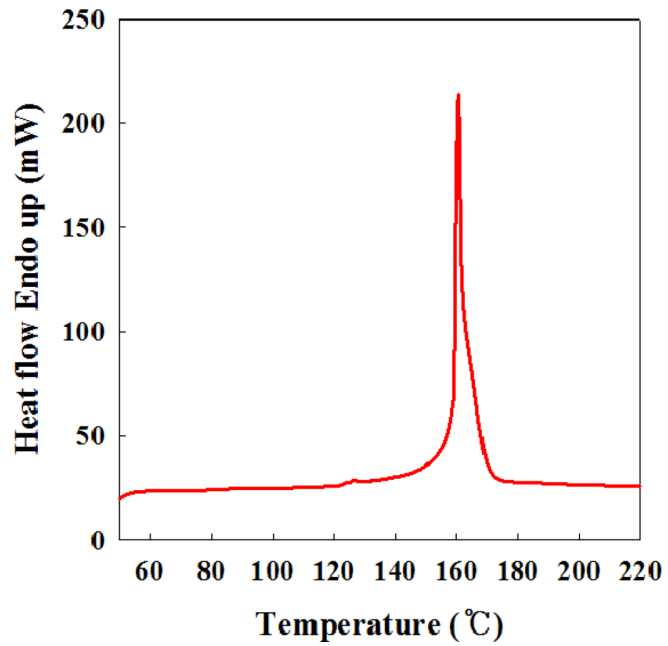

Figure 1. TGA and DSC results of commercial thermally expandable microcapsule. 


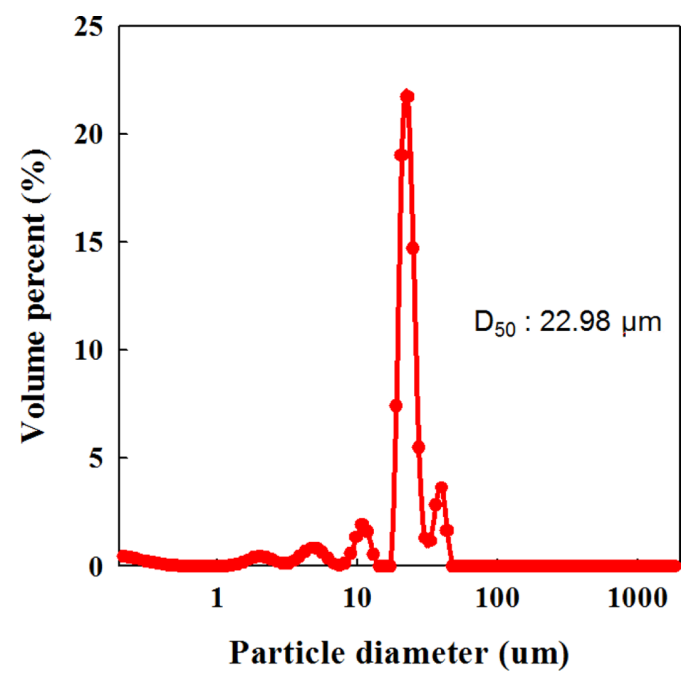

Figure 2. Particle size and distribution of commercial thermally expandable microcapsule.

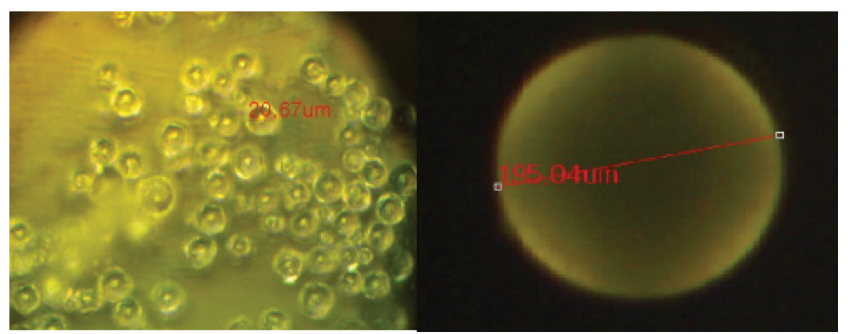

Figure 3. OM image of commercial thermally expandable microcapsule. (Left) before expansion; (Right) after expansion.

제작된 시편의 밀도 인장강도 굴곡 및 충격강도는 Table 2에 정리하였다. 화학 발포제 및 열팽창 캡슐 모두 함량증가에 따 라 밀도는 감소하였으며, 이는 화학발포제 및 열팽창 캡슐 모 두 고분자 매트릭스 상에서 함량증가에 따른 void 발생을 증 가시킨 것으로 기인된다. Void 증가에 따른 영향으로 화학발 포제와 열팽창 캡슐의 물성이 감소하는 경향을 보였지만 실 험 결과에서 특이한 점은 열팽창 캡슐의 경우 함량 증가에 따른 인장강도 및 충격강도 감소율이 화학발포제의 측정값
대비 소폭 우세한 것을 보여주었다(Figure 4,5 ). 이러한 물성 차이는 Figure 6 의 $\mathrm{OM}$ 사진을 발포제에 따른 발포된 $\mathrm{PP}$ 수 지의 단면 분석을 통하여 유추할 수 있다. 화학발포제의 경 우 발포반응개시 후 기포가 불규칙적으로 발생하며 기포간 융합으로 인하여 상대적으로 큰 void를 형성하나, 열팽창 캡 슐의 경우 열팽창 반응시 단일 캡슐이 개별적으로 팽창하고 적정온도에서는 캡슐의 분해가 이루어 지지 않아 캡슐의 형 상을 유지하기 때문에 발포캡슐간 융합으로 인한 거대 void 의 발생 확률이 낮다. 이처럼 수지상에서 각기 다른 형태로 발생된 void의 형태는 사출물이 외부로부터 충격을 받았을 때 발생되는 crack의 진행속도에 영향을 미쳐 기계적 특성에 영향을 준 것으로 예상된다. 동일 함량의 발포제가 사용되었 을 때 보다 균일하고 미세한 발포를 형상한 발포폼의 물성이 일반적인 발포폼 대비 충격강도 및 인장강도가 높은 경우는 여러 논문을 통해서 검토되었다. ${ }^{17,18}$ 인장강도의 경우도 마찬 가지로 매트릭스 상에서 발생한 셀의 크기에 따른 영향이 큰 것으로 판단된다.

발포수지의 화학적 거동과 셀의 크기 및 크기 분포에 따른 물성특성을 예측하기는 일반적으로 매우 어렵지만, 매트릭스 수지와 발포된 수지와의 밀도차이 등을 활용하여 기계적 특 성을 예측할 수 있다.

발포수지의 강성 예측은 Power-law를 이용하는 방법이 있 으며, 상대밀도에 실험상수를 대입하여 비교적 간단하게 값 을 예측할 수 있다. ${ }^{19,20}$

$$
\frac{M_{\mathrm{f}}}{M_{\mathrm{m}}}=\left(\rho_{\mathrm{r}}\right)^{\mathrm{n}}
$$

식 (1)에서 $M_{\mathrm{f}}$ 는 발포수지의 기계적 물성이며, $M_{\mathrm{m}}$ 은 동일 수지의 발포가 적용되지 않았을 때의 기계적 물성이며, $\rho_{\mathrm{r}}$ 은 상대밀도 식 (2)를 지칭한다. 실험상수(n)의 경우 일반적인 고 분자는 1 과 3 사이 값을 갖는다.

$$
\rho_{\mathrm{r}}=\frac{\rho_{\mathrm{f}}}{\rho_{\mathrm{m}}}
$$

단순히 밀도변수에 의한 인장강도 변화는 실험식과 해석식

Table 2. Physical Properties of PP Foam Produced by Blending with the Chemical Blowing Agent (CBA) and the Thermally Expandable Microcapsule (TEM)

\begin{tabular}{ccccccccc}
\hline & \multicolumn{3}{c}{ CBA } & \multicolumn{3}{c}{ TEM } \\
\hline Content of blowing agent & 2 & 2.5 & 3.2 & 4 & 2 & 2.5 & 3.2 & 4 \\
\hline Density $\left(\mathrm{g} / \mathrm{cm}^{3}\right)$ & 1 & 0.92 & 0.88 & 0.72 & 0.99 & 0.95 & 0.78 & 0.73 \\
Tensile strength $(\mathrm{MPa})$ & 20.7 & 20.1 & 16.4 & 14.2 & 20.5 & 19.7 & 17.9 & 17.5 \\
Elongation & 35 & 27 & 30 & 20 & 27 & 20 & 22 & 11 \\
Flexural modulus $(\mathrm{MPa})$ & 2050 & 1820 & 1711 & 1670 & 1950 & 1854 & 1742 & 1650 \\
Flexural strength $(\mathrm{MPa})$ & 28 & 27 & 25 & 23 & 30 & 28 & 25 & 22 \\
Izod $(\mathrm{kgcm} / \mathrm{cm})$ & 18.8 & 13.4 & 12.1 & 11.4 & 22.1 & 19.1 & 17.2 & 14.3 \\
\hline
\end{tabular}




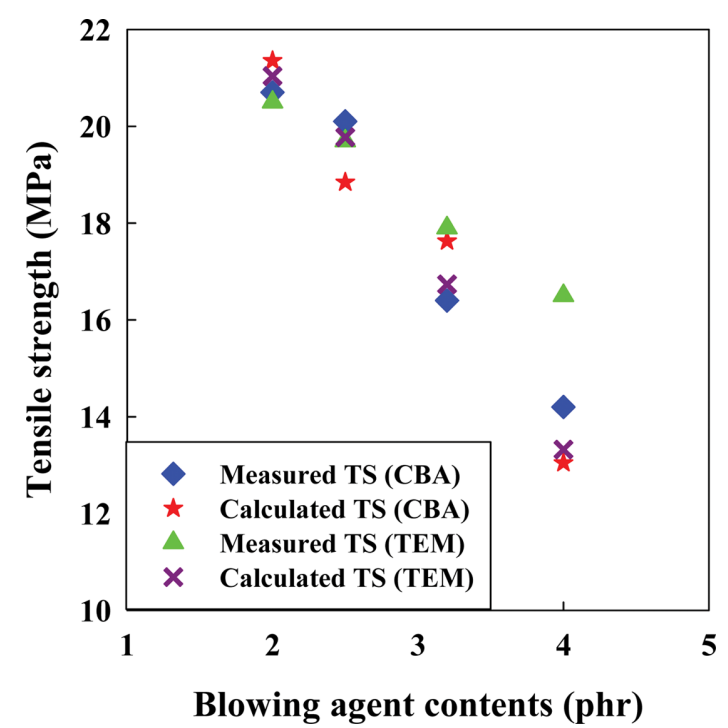

Figure 4. Comparison of tensile strength of PP containing chemical blowing agent, and thermally expandable microcapsule.

의 경향이 일치하나 함량이 증가할수록 해석값 대비 실험값 이 다소 높은 경향을 보여주었다. 이는 발포수지의 물리적 특 성이 밀도 이외에 다른 변수가 있음을 반영한다. 발포 사출 의 경우 동일 사출물 내에서도 시편의 물성편차가 일반적인 사출대비 큰 편인데, 가공조건에 따른 편차가 실질적으로 큰 영항을 끼칠 수 있을 것으로 판단된다.

발포수지의 충격 특성 값 또한 수치적으로 예측이 가능하 며 식 (3)을 통하여 관련된 해석식을 서술하였다.

$$
\frac{I_{\mathrm{f}}}{I_{\mathrm{m}}}=\left(\rho_{\mathrm{r}}\right)^{\mathrm{m}_{1}}\left(\frac{h_{\mathrm{f}}}{h_{\mathrm{m}}}\right)^{\mathrm{m}_{2}}\left(\frac{N_{\mathrm{f}}}{N_{\mathrm{s}}}\right)^{\mathrm{m}_{3}}
$$

$\mathrm{m}_{1}$ 과 $\mathrm{m}_{2}$ 은 수지별 실험상수 값이며 폴리프로필렌의 경우 2 와 4 사이 값을 갖는다. $h$ 는 발포수지와 비발포수지 시편의 두께이나, 본 연구에서 사용한 시편의 두께는 모두 동일하므

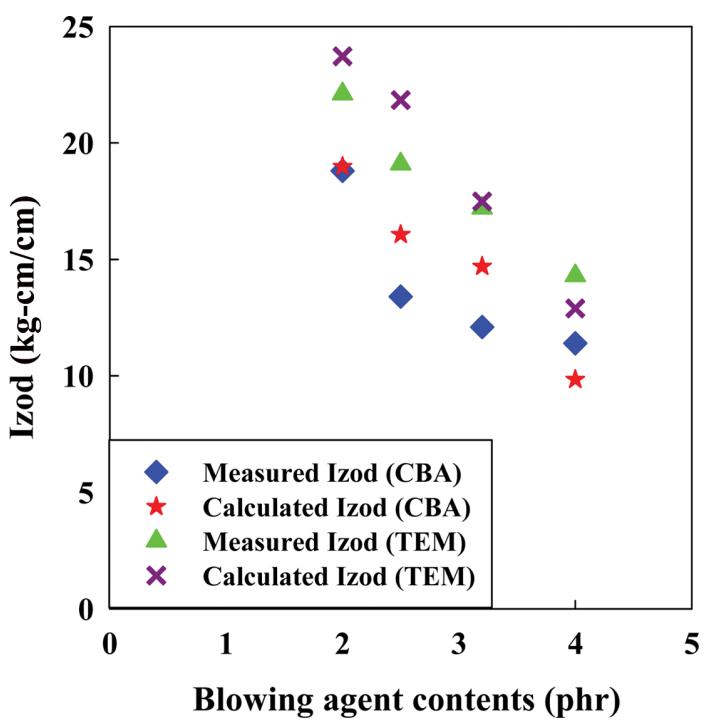

Figure 5. Comparison of impact strength of PP containing chemical blowing agent, and thermally expandable microcapsule.

로 무시될 수 있다. $N_{\mathrm{s}}$ 는 표준 발포셀 밀도이며 $\left(1.1 \times 10^{6} \mathrm{cell} /\right.$ $\left.\mathrm{cm}^{3}\right),{ }^{18} N_{\mathrm{f}}$ 는 실험셀 밀도이며 단위면적 $\left(\mathrm{cm}^{3}\right)$ 당 셀의 개수에 대한 값이며 ${ }^{21}$ 식 (4)와 같이 표현된다. $A$ 와 $M$ 은 현미경 측 정 범위와 확대비율이며, $N$ 은 셀의 개수이다.

$$
N_{\mathrm{f}}=\left(\frac{N M^{2}}{A}\right)^{3 / 2}
$$

충격강도 값의 경우도 해석값과 유사한 경향을 보이긴 하 였지만 인장강도와 달리 값의 차이가 다소 큰 것으로 판단되 며, 이는 시편의 두께를 동일하게 간주한 것에 따른 수치적 인 편차발생과 여러 다른 변수들로 기인한 것으로 판단된다. 일반적으로 발포수지의 경우 모든 시편의 발포패턴이 동일하 지 않기 때문에 특정한 해석식으로 정확히 예측하기란 쉽지 않다.

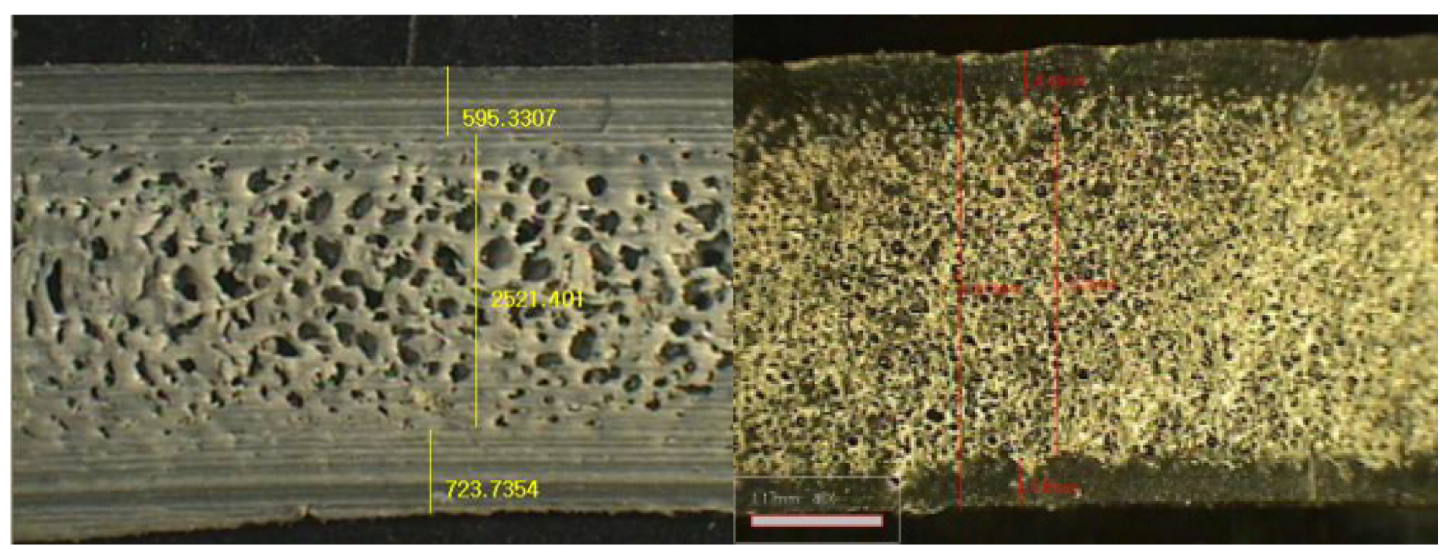

Figure 6. Cross section OM images of PP foam containing (Left) chemical blowing agent; (Right) thermally expandable microcapsule. 


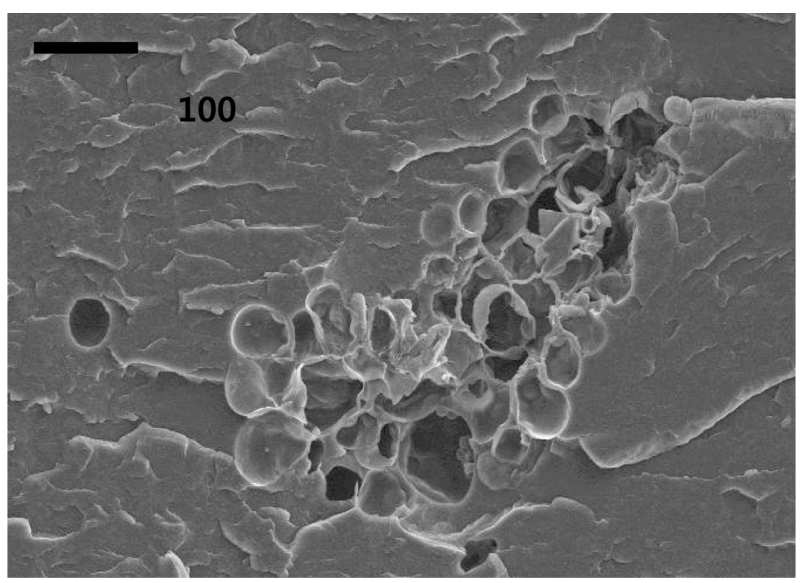

Figure 7. Cross section SEM image of TEM in PP matrix.

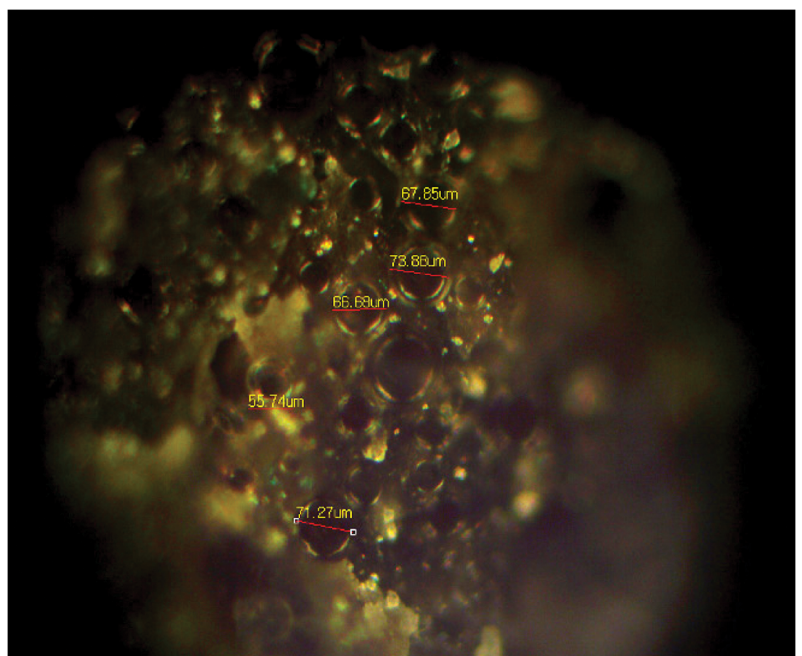

Figure 8. Cross section OM image of TEM in PP matrix.

Figure 7과 Figure 8은 열팽창 캡슐을 적용한 PP 시편의 단 면을 액체질소로 급속 냉각한 후 단면을 각각 SEM과 광학 현미경으로 관찰한 사진이다. SEM을 통한 분석 시 캡슐의 형상은 일정 수준 유지된 것으로 추정되나, 파괴된 캡슐의 형 상이 많은데, 이는 시편의 단면을 관찰하기 위해 시편 절단 시 캡슐이 동시에 변형을 받았거나, SEM 분석을 위한 시편 의 전도성 코팅시 캡슐이 외부 자극에 의하여 변형된 것으로 추정된다. 이러한 현상은 사출가공 전 열팽창 캡슐을 $\mathrm{SEM}$ 분석할 경우에도 볼 수 있는데, 광학현미경을 통한 관찰과 달 리 SEM 분석시에는 캡슐의 형상이 구형이 아니며 다소 변 형된 형태의 캡슐 형상을 보인다. 따라서 열팽창 캡슐의 SEM 분석시에는 상기 현상을 고려할 필요가 있음을 반영한다. Figure 8은 동일 조건에서 광학현미경을 통한 시편의 단면을 관찰한 사진이며, SEM 분석시와는 달리 캡슐의 변형이나 파 괴가 관찰되지 않으며, 구형 상태의 캡슐이 온전히 팽창되어
Table 3. Density of PP Foams with Different Core Back Distance

\begin{tabular}{ccccc}
\hline Core back distance $(\mathrm{mm})$ & 1.0 & 1.5 & 2.0 & 2.5 \\
\hline Density $\left(\mathrm{g} / \mathrm{cm}^{3}\right)$ & 0.98 & 0.91 & 0.78 & 0.70 \\
\hline
\end{tabular}

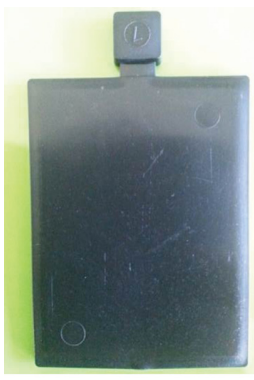

(a)

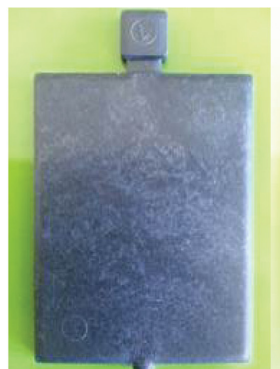

(b)

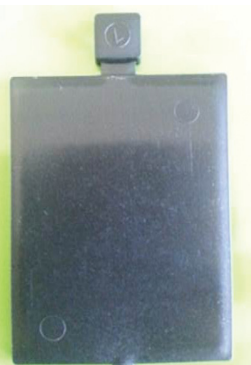

(c)
Figure 9. Appearance of injection molded specimen of (a) PP only; (b) PP with chemical blowing agent; (c) PP with TEM.

있는 것을 관찰할 수 있다. 하지만, 초기 평가 시 수행한 열 팽창 캡슐의 경우, $200{ }^{\circ} \mathrm{C}$ 노출시 캡슐의 최대 크기가 약 $190 \mu \mathrm{m}$ 이상 팽창되는 것으로 추정되나, 단면의 현미경 사진 을 통해서는 그 보다 작은 약 $60 ~ 80 \mu \mathrm{m}$ 정도의 팽창성능을 보여주었다. 이는 사출기의 가공온도가 $190{ }^{\circ} \mathrm{C}$ 이며 실제 수 지가 받는 shear force를 고려할 경우 열팽창 캡슐의 코어에 위치한 발포가스가 받게 되는 팽창온도로 충분할 것으로 판 단되지만, 가공조건이 최적화되지 않은 것으로 기인한 것으 로 보인다. 따라서 사출가공 시 금형후퇴(core back)를 더 크 게 설정하거나, 수지의 주입량을 컨트롤하여 추가적으로 팽 창률을 향상시킬 수 있을 것으로 판단된다.

Table 3에는 사출가공 시 금형후퇴의 거리를 달리하여 제 조된 시편의 밀도차이를 정리하였다. 금형후퇴 거리에 따른 차이만을 확인하기 위하여 다른 가공조건은 기존과 동일하게 하고 시편을 제조하였기 때문에 본 실험결과가 열팽창 캡슐 로 인한 최적화된 결과로 볼 수는 없지만, 금형후퇴에 따라 밀도차이가 발생하는 것을 볼 수 있으며, 금형후퇴가 클수록 시편의 밀도가 감소하는 것은 캡슐의 팽창이 기존보다 용이 해졌기 때문으로 추정된다.

Figure 9는 화학발포제와 열팽창 캡슐을 이용한 사출물의 외관을 보여주고 있다. 화학발포제의 경우 표면에 gas mark 가 발생한 반면 열팽창 캡슐의 경우는 상대적으로 gas mark 의 발생이 낮은 것을 볼 수 있다. 이러한 사출물의 외관 특성 차이는 화학발포제를 이용하여 발포된 경우 발포시 발생된 기 체가 사출물 표면에 잔류되는 반면에 열팽창 캡슐의 경우 캡 슐내 위치한 가스가 외부로 전이되기 보다는 캡슐내에 갇혀 있기 때문에 최종제품의 표면품질에 영향을 줄 수 있는 확률 이 미미해져 외관품질 구현에 보다 유리한 것으로 판단된다. 
하진욱 - 정선경 - 이평찬 - 황예진 - 남병국 - 한인수 - 곽성복 - 이재용

\section{결 론}

본 연구에서는 열팽창 캡슐과 화학발포제를 통한 PP 발포 수지의 물성을 직접 비교하였으며, 발포제 함량증가에 따른 수지의 물성저하 및 경량화 효율 상승 등에 대해서 비교하였 다. 또한 일반적인 화학발포제와 달리 열팽창캡슐의 경우 함 량증가에 따른 충격강도 감소경향이 상대적으로 적은데, 그 원인은 PP 매트릭스에서 화학발포제에 의해서 발생되는 void 의 형태와 열팽창 캡슐로 인하여 발생된 void의 형상 차이로 인한 것으로 판단된다. 이러한 발포제의 발포 메커니즘 차이 는 최종제품의 외관에도 영향을 줄 수 있음을 확인하였다. 본 연구에서는 기존에 사출가공을 통한 제품에 적용된 사례가 많지 않은 열팽창 캡슐을 이용하여 경량부품 제조 가능성을 확인하였으며, 향후 새로운 형태의 경량소재 개발 응용에 활 용될 수 있을 것으로 판단된다. 본 연구에서는 소재의 물성 적인 측면에 대한 고찰로 열팽창 캡슐이 화학발포제 보다 응 용개발이 유리한 것으로 보여지나 실질적으로 사출가공 운용 을 위한 가공조건 범위(processing window) 및 소재가격은 기 존 화학발포제가 보다 우위에 있으므로 여러 가지 변수를 동 시에 고려해야 한다.

감사의 글: 이 본 논문(연구)는 산업자원부 산업융합원천 기술개발사업(과제번호: 10045051)의 지원으로 수행된 결과임.

\section{참 고 문 헌}

1. J. Park, J. Lee, S. Kim, J. Kim, and K. Ahn, Transactions of KSAE, 1, 123 (2013).

2. D. W. Kim, J. W. Yoon, S. Park, K. Kim, and T. Lee, Int. J. Autom. Techn., 14, 955 (2013).

3. C. S. Park, High Performance Epoxy Resins in Composite
Application, SAMPE Korea Symposium Il-San, S. Korea, Oct. (2013).

4. K. H. Yoon, J. W. Lee, and Y. C. Kim, Polym(Korea), 37, 494 (2013).

5. D. Y. Hwang, K. D. Han, D. Han, K. I. Lee, and K. Y. Lee, Polym(Korea), 24, 538 (2000).

6. K. Hikita, JSAE Review, 23, 239, (2002).

7. D. S. Morehouse and R. J. Tetreault, U.S. Pat. 3,615,972 (1971).

8. M. Jonsson, O. Nordin, A. L. Kron, and E. Malmstrom J. Appl. Polym. Sci., 118, 1219 (2010).

9. M. Jonsson, O. Nordin, E. Malmstrom, and C. Hammer, Polym. 47, 3315 (2006).

10. Y. Kawaguchi and T. Oishi, J. Appl. Polym. Sci., 93, 505 (2004).

11. Y. Kawaguchi, Y. Itamura, K. Onimura, and T. Oishi, J. Appl. Polym. Sci., 96, 1306 (2005).

12. M. Tomalino and G. Bianchini, Prog. Org. Coat., 32, 17 (1997).

13. M. Jonsson, O. Nordin, and E. Malmstrom, J. Appl. Polym. Sci., 121, 369 (2011).

14. Y. Zhao, C. Wang, Y, Bai, G. Chen, M. Jing, and B. Zhu, J. Colloid Interf. Sci., 32948 (2009).

15. B. N. Kolarz, M. Wojaczynska, J. Bryjak, and B. Pawlow, React. Polym., 23, 123 (1994).

16. M. Jonsson, O. Nordin, A. L. Kron, and E. Malmstrom, J. Appl. Polym. Sci., 117, 384 (2010).

17. S. Doroudiani, C. B. Park, and M. T. Kortschot, Polym. Eng. Sci., 38, 1205 (1998).

18. E. H. Tejeda, C. Z. Sahagun, R. Gonzalez-Nunez, and D. Rodrigue, J. Cell. Plast., 41, 417 (2005).

19. D. Klempner and K. C. Frisch. Handbook of Polymeric Foam and Foam Technology, Hanser, New York, 1991.

20. L. J. Gibson and M. Ashby, Cellular Solids: Structure and Properties, 2nd Edition, Cambridge University Press, Cambridge, 1997.

21. V. Kumar and N. P. Suh, Polym. Eng. Sci., 30, 1323 (1990). 